\title{
The Constraints to Sago Development and Improvement Efforts in Siau Tagulandang Biaro (Sitaro) Islands
}

\author{
Jefny B. Markus Rawung ${ }^{1, *}$, and Rita Indrasti $^{2}$ \\ ${ }^{1}$ The Assessment Institute for Agricultural Technology of North Sulawesi. Manado. Indonesia \\ ${ }^{2}$ Centre of Assessment and Agriculture Development. Bogor. West Java. Indonesia
}

\begin{abstract}
Sago (Metroxylon sago Rottb) is very suitable as a food ingredient because it contains carbohydrates in starch form and high calories. In eastern Indonesia, the sago plant has important social, economic, and ecological roles for most societies because it is also used as a staple food. On the contrary, its development still requires powerful and maximum support. This study aims to describe the diversity of cultivation technology applications and the constraints of sago development. The research was carried out in a plantation area in the Siau Tagulandang Biaro (Sitaro) Islands Regency, North Sulawesi Province, from June to December 2016. The research used a survey method with semi-structured interview techniques on 60 respondents and focus group discussion (FGD) techniques. The research results that have been carried out indicate that farmers have not fully implemented good sago cultivation technology. However, they understand the economic value of this plant. The components of cultivation that were still weak were the weed control aspects and pest and disease control, as well as the post-harvest aspects in terms of sago pith processing techniques.
\end{abstract}

\section{Introduction}

Indonesia holds a wide genetic diversity and planting area of the sago palm. Sago grows naturally in tropical areas, namely swampy areas, such as in Papua, Maluku, Sumatra, Kalimantan, Sulawesi, and Bali. It is estimated that the total area of sago forest in Indonesia is around 1.128 million hectares, and there are still around 130,000 hectares of technical culture areas for sago plants [1]. The sago plant belongs to the species Metroxylon sago (Metroxylon sago Rotti), belongs to the palm family, and is divided into two groups with thorny or spiny petioles. The spiny includes Metroxylon rumphii mart, which is the main type in the sago group. Sago is a monocot plant belonging to Spadiciflora, family Palmae, genus Metroxylon and species Metroxylon spp. This plant is distributed in the wet tropics of Southeast Asia and Oceania, especially growing in swampy, brackish, or waterlogged lands [2]. Sago is considered to be potential not only for food production but also for ethanol production. Sago has great potential to be developed, and sago is an alternative food

*Corresponding author: jbmarkusrawung2000@yahoo.com 
substitute for rice because it has high nutritional and vitamin content. Sago is capable of producing dry starch of 15-24 tons per hectare. Sago not only produces the largest starch but also produces starch throughout the year. The sago per stem can produce about $200 \mathrm{~kg}$ of wet sago starch per year [3]. The starch storage organ of sago is unique compared to other starch sources such as rice, corn, Etc. [4].

According to [5] based on the research in Maluku there has been a change in consumption of sago to rice due to several factors, namely (1) the existence of transmigrants who encourage the conversion of sago land to rice fields, (2) rice has become a prestigious commodity that can improve social status besides being available inadequate and easily obtainable quantities, (3) the age of harvest for sago is relatively long, around 8 to 10 years, (4) local governments are less focused on paying attention to sago as local food so that land is converted into paddy fields, (5) less ongoing socialization of eating traditions sago from generations, (6) not available sago products inadequate quality, quantity, time and place, (7) limited product diversification and (8) increasing socio-economic status of the community. Sago has been known since 1,200 based on records in Chinese writings; for example, Marcopolo discovered sago in Sumatra in 1298, and the sago factory in Malacca was recorded in 1416 [6]. However, according to [7], its distribution covers low coastal areas and river basins to an altitude of $1,250 \mathrm{~m}$ above sea level with $4,500 \mathrm{~mm}$ of rainfall/year. However, the best production is in areas with an altitude of 0-400 asl.

This study aims to describe the diversity of cultivation technology applications, constraints on sago development, and improvement efforts. Thus, it is hoped that the development of this plant in the future will be more widespread and be considered a commodity that brings significant benefits and added value to farmers.

\section{Methodology}

\subsection{Method}

The research was carried out in a plantation area in the Siau Tagulandang Biaro (Sitaro) Islands Regency, North Sulawesi Province, from June to December 2016. The research used a survey method with semi-structured interview techniques and focus group discussion (FGD) techniques.

\subsection{Data Collection}

The data used in this study are primary data from respondents as many as 60 palm-based farmer households in each production center in each location. Besides, a focus group discussion (FGD) of 15 participants was also held at the sub-district and district levels focused on the research topic.

\subsection{Data Analysis}

Data analysis used cross-tabulation analysis and binomial non-parametric significance test. Knowledge of the sago cultivation system was identified in the understanding of farmers regarding the components of knowledge of the sago cultivation system according to the Ministry of Agriculture number: 134/permentan/ot.140/12/2013 regarding good Sago Cultivation Guidelines (Metroxylon spp), which includes: (1) Requirements grow; (2) Selection of parent trees and provision of planting material; (3) Nursery and nurseries; (4) Site selection; (5) planting; (6) Weed control; (7) Pest and disease control; (8) Harvest and 
Processing; (9) sago pith processing techniques; (10) Processing of sago starch. All respondents cultivate sago plants using an intercropping farming system with forestry plants, plantation crops, and food crops.

\section{Results and Discussion}

\subsection{Farmers' knowledge on good sago cultivation}

Table 1 shows that almost all respondents have good knowledge of sago farming.

Table1. Farmers' knowledge about good sago cultivation

\begin{tabular}{|c|l|c|c|c|c|c|c|}
\hline \multirow{2}{*}{ No. } & \multirow{2}{*}{ Knowledge component } & \multicolumn{2}{|c|}{ High } & \multicolumn{2}{c|}{ Middle } & \multicolumn{2}{c|}{ Low } \\
\cline { 3 - 8 } & $\begin{array}{c}\text { Freque } \\
\text { ncy }\end{array}$ & $\%$ & $\begin{array}{c}\text { Frequ } \\
\text { ency }\end{array}$ & $\%$ & $\begin{array}{c}\text { Freque } \\
\text { ncy }\end{array}$ & $\%$ \\
\hline 1 & Requirements for growth & 52 & 86.67 & 7 & 11.67 & 1 & 1.67 \\
\hline 2 & $\begin{array}{l}\text { Selection of parent trees and } \\
\text { provision of planting }\end{array}$ & 10 & 16.67 & 35 & 58.33 & 15 & 25.00 \\
\hline 3 & Nursery and Nurseries & 15 & 25.00 & 20 & 33.33 & 25 & 41.67 \\
\hline 4 & Site selection & 44 & 73.33 & 13 & 21.67 & 3 & 5.00 \\
\hline 5 & Planting & 35 & 58.33 & 23 & 38.33 & 2 & 3.33 \\
\hline 6 & Weed control & 59 & 98.33 & 1 & 1.67 & 0 & 0.00 \\
\hline 7 & Pest and disease control & 58 & 96.67 & 0 & 0.00 & 2 & 3.33 \\
\hline 8 & Harvest and processing & 15 & 25.00 & 30 & 50.00 & 15 & 25.00 \\
\hline 9 & $\begin{array}{l}\text { Sago pith processing } \\
\text { technique }\end{array}$ & 20 & 33.33 & 22 & 36.67 & 18 & 30.00 \\
\hline 10 & $\begin{array}{l}\text { Application of plant } \\
\text { integration systems }\end{array}$ & 49 & 81.67 & 5 & 8.33 & 6 & 10.00 \\
\hline
\end{tabular}

The components of cultivation that have been well controlled are the requirements for growing sago palms, aspects of weed control, and pest control. It is related to the farmers' habit of always cleaning their gardens because of other additional crops being cultivated. However, plant disease is still a problem because the farmers do not really understand the cause when the sago es. The aspects that have not been properly mastered the selection of mother trees and the provision of planting material, as well as the post-harvest aspects in terms of sago pith processing techniques. The low survival rate of sago palm in the nursery once have been experienced in Philippine, and then they developed a propagation technique to overcome the problem [8]. As sago becomes a potential commodity, it is important to improve sago farmers' capability [9].

The post-harvest aspect that is closely related to improving the quality of sago production was still not optimal for farmers, especially those related to processing sago starch into food and as an alternative energy material. Even so, cumulatively, it can be explained that the respondent farmers have high knowledge (64.84\%) of the sago cultivation system. One of the important information related to the sago cultivation system was farmers' high perception of the farming diversification pattern (integration). Of the 60 respondents, it turned out that 49 respondents or $81.67 \%$ developed their sago farming with an integration pattern with food crops, plantation crops, or timber plants. 


\subsection{Current Condition of Sago Plants}

The most extensive land distribution for sago trees in Indonesia, apart from Maluku, is in Papua, Riau, Sulawesi, and Kalimantan. Until now, the area of sago plantations in Indonesia remains uncertain. Starch production of Sagu Baruk in the location want wet sago $71.97 \mathrm{~kg}( \pm 26.97)$ or starch dry sago $43.18 \mathrm{~kg}( \pm 16.18)$. Plant age: $10 \pm 2$ years. The carbohydrate and starch content percentage is almost the same as the Metroxylon sago, with the carbohydrate content of $86.9 \%$ and starch content of $80.6 \%$. It has a small stem to be cultivated as a yard plant ornament. New sago processing is easier compared to Metroxylon sago. Has strong and absorbent roots water and can grow on land steep so usable as a conservation and restoration crop critical land (former coal mining land).

Rehabilitation of sago plants can improve productivity until 1.5 times, which means that productivity becomes 6 tons of dry starch/ha/year. If rehabilitation is carried out, the total production of dry sago flour can reach 188,160 tons or rice equivalent to 110,682 tons, which means that it can fulfill the food demand of 819,869 people or $53 \%$ of the inhabitants of Maluku.

\subsection{Prospect of Sago Development}

The processing of sago stem into sago flour increases the added value ratio by approximately $69.09 \%$. In the future, sago flour will be widely used for industrial purposes, including for making bread, noodles, cakes, and high fructose syrups, adhesives, and easily biodegradable plastics. Sago starch is a staple food for indigenous people of Maluku and Papua, especially those who live in lowland areas. Sago starch is also used in the pharmaceutical, paper, ethanol, and textile industries. Meanwhile, sago processing waste can be used as animal feed. The identification results from research there are about 17 to 20 species of sago in Sentani, Jayapura Regency, Papua, and the species that developed is Metroxylon rumpii Martius.

Sago starch is one of the most potential food ingredients and can produce many carbohydrates. Sago starch can then be used as a staple food or raw material for snacks such as empek-empek, dodol, ongol-ongol, and other raw materials for food. Sago starch contains $3.69-5.96 \%$ of dietary fiber with a Glycemic Index (GI) 28 , which is in the low category because it is less than 55 [10]. Meanwhile, according to [11], sago starch contains about $27 \%$ amylose and $73 \%$ amylopectin.

Besides being used as a food source, sago can also be used as animal feed. A sago derivative product that can be developed and is currently widely used as animal feed is single-cell protein [12]. Sago pests or sago worms are often hunted by farmers to be used as animal feed and fish. Likewise, the sago industrial waste can be used as an alternative energy source with a high feasibility value [13]. Sago-based bio-ethanol has the potential to be developed in this research area. The strategies used to develop bio-ethanol include sago development strategies, bio-ethanol industry development strategies, and government policy support strategies [14]. The sago is not the only potential as an alternative source of food, animal feed, and energy source, but also potential to reduce $\mathrm{CO} 2$ emission from tidal swamp [15].

\subsection{Constraints on Sago Plants Development}

Some of the obstacles to the development of sago in Indonesia include (1) Lack of attention from the government, government policies are more dominant and focused on increasing food commodities production, and the dominant food commodity leads to rice direction. It can be seen from government intervention activities, which only focus on intensification 
programs and rice import policies. Meanwhile, In Malaysia, the government has been making great efforts to develop the sago plantation through an estate plantation scheme [16]. The government in promoting the transmigration program certainly has a positive meaning in growth and regional development. However, some problems arise, namely the government's lack of equal attention to local food sources. The government seems to generalize the national food problem. The Sitaro Islands, of course, have to sacrifice sago land because it is to support government programs that pay more attention to rice food. Because most of the consumer goods such as rice and vegetables are imported from Manado and Bitung. (2) Limited marketing for sago commodities and processed products. Marketing has always been a problem for the agricultural world. Lack of market is also triggered by the lower public consumption of local food. Besides, the diversification of sago products is still limited. (3) Inefficient use of technology for processing sago. It is in line with the report that cultivation technology and plant material are the constraints on sago development [15]. The reality so far, farmers are less motivated to increase production through the use of production technology. At the farmer level, the tools used are straightforward due to limited capital. The need is only fulfilled for the surrounding area because the resulting product is minimal. The price of sago is also meager compared to other food prices. (4) Competition for sago food against other foods. This food competition includes quality, taste, availability of goods, demand, and market. The government also has a stake in terms of the policy. In this case, sago is still unable to compete with other foods where food policy is usually long term and not speculative, trapped in a seasonal atmosphere but must be based on domestic resources' capacity. Local governments will automatically implement the policies decided by the central government compete with other foods where food policy is usually long term and not speculative, not only trapped in a seasonal atmosphere but must be based on the capacity of domestic resources. Local governments will automatically implement the policies decided by the central government.

\subsection{Remedial Efforts}

Initially, it is required to promote or socialize. Therefore, the consumers like to eat sago, at least to let them know more about sago. Sago contains $11.0 \mathrm{mg}$ of Ca, $13.0 \mathrm{mg}$ of P, $1.5 \mathrm{mg}$ of $\mathrm{Fe}$, and $0.01 \mathrm{mg}$ of vitamin B for content in 100 grams of sago. So that in 100 grams of sago, there are 85.9 grams of carbohydrates, higher than 80.4 grams of rice. The calorie content in sago is 357 calories, which is slightly different from rice for 366 calories. Moreover, the fat content is 0.2 grams, slightly lower than rice 0.5 grams. With this content's composition, sago has highly soluble carbohydrate content but less content of mineral protein and fat. Along with the results of these studies, sago is an important food source for humans.

A strategy and policy support from the central government and local governments is needed in the form of regulations on sago plants. One example of sago area in Indonesia is the area of sago in Sitaro Islands, which probably decrease caused by sago land conversion into rice paddy, resettlement villages, offices, roads, and another plantation [17]. Providing business capital for sago farmers is necessary because of the limited capital owned by the farmers. Assisting and transferring technology and establishing partnerships with prominent entrepreneurs to penetrate the international market. The long-term effort for the government is to reduce rice consumption. Sago is to be more widely socialized. 


\section{Conclusions and Recommendations}

In general, sago farmers already know a good sago cultivation system (64.84\%). It is important for determining the status of farmers' knowledge of the components of good sago cultivation. It is necessary to identify the diversity of sago plants in Indonesia. The development of sago palms in Indonesia is still hampered by, among others, a lack of attention from the government. Improvement efforts must be made with the support of related parties.

\section{References}

1. H. Lakuy, J. Limbongan, Pros. Nas Sagu, Manado, (2003)

2. D.L. Scuiling, M. Flach, Agri. Univ. 34 p. (1985)

3. A.R. Wahid, M. S. Lestari, J. Litbang Pertanian, 28, 2 (2009)

4. L.W.K. Lim, H.H. Chung, H. Husain, K. Bujang, J. Trop. Agri. Sci. 42 (2): 435-451 (2019)

5. M.E. Hetharia, Pros. Sagu. Univ. Pattimura, hlm. 52-59 (2006)

6. T.S. Ong, Paper of the First Inter. Sago Symp. Kuch, Mas, (1977)

7. C. Oates, A. Hicks, New frontiers of sago palm studies. Tokyo: Univ. Ac. Press. $27-$ $36(2002)$

8. L.J. Teodosio, M.A. Quevedo, E.P. Vedasto EP, M.M. Teodosio, Philip. J. Crop. 42, 79-80. (2017)

9. M. Ahmad, Inter. J. Adv. Sci. Eng. Inf. Tech. 4 (3): 5-9 (2014)

10. E.Y. Purwani, Widaningrum, H. Setiyanto, E. Savitri, R. Tahir, Balai Besar PPP BPPT, (2006)

11. J.B. Alfonfs, A.A. Rivaie, J. Persp, 10. 2 (2011)

12. H. Haryanto, P. Pangloli, Kanisius. ISBN 979-413-726-X. Yog. (1992).

13. Y.K. Wan, J. Sadhukhan, K.S. Ng, K.S Ng Denny, Chem. Eng. Res and Dsgn. DOI: 10.1016/j.cherd.2015.11.001. (2015)

14. S. Bustaman. J. Persp, 7 (2): 65-79, (2015)

15. M. Syakir, E. Karmawati, J. Persp, 12 (2): 57-64 (2013)

16. H.M. Nai, A.N. Yaakub, D.A.A Hamdan, Int. J. of Agro. 2: 1-6 (2016)

17. W. Girsang, Sago Palm. Springer, Sin. https://doi.org/10.1007/978-981-10-5269-98, (2018) 